\title{
PENINGKATAN KAPASITAS KELEMBAGAAN GARAM RAKYAT UNTUK MENDUKUNG INDUSTRI GARAM DI INDONESIA
}

\section{Enhancing Capacity of Salt Institutional To Support The Salt Industry in Indonesia}

\author{
*Mei Dwi Erlina dan Tikkyrino Kurniawan \\ Balai Besar Penelitian Sosial Ekonomi Kelautan dan Perikanan \\ Gedung Balitbang KP I Lt. 4 \\ Jalan Pasir Putih Nomor 1 Ancol Timur, Jakarta Utara \\ Telp: (021) 64711583 Fax: 64700924r 2015 \\ *e-mail: mei.dwi.erlina@gmail.com \\ Diterima 12 Februari 2015 - Disetujui 25 Nopember 2015
}

\begin{abstract}
ABSTRAK
Kementerian Kelautan dan Perikanan (KKP) telah memutuskan bahwa usaha garam dari hulu sampai hilir memiliki prospek usaha yang stategis. Kebijakan ini tidak hanya memperhatikan kuantitas dan kualitas garam, tetapi juga memperhatikan aspek sosial ekonomi para petambak, pengumpul, pengolah, pedagang garam. Selain itu, aspek kelembagaan(Kelompok Usaha Pegaraman dan Koperasi Garam) agar terjadi peningkatan kesejahteraan, pemasaran, harga jual garam, serta impor garam. Tujuan penelitian ini adalah : (1) Melakukan kajian tentang kinerja kelembagaan dan pelaku usaha garam rakyat; (2) Melakukan kajian tentang upaya pembentukan badan penyangga garam untuk mengawasi produksi dan distribusi garam; (3) Melakukan kajian terkait dengan kinerja POKJA pegaraman pada masing-masing lokasi; dan (4) Melakukan kajian tentang upaya penguatan kelembagaan koperasi sebagai lembaga penyangga garam di lokasi. Metode analisis data yang digunakan dalam kajian ini adalah analisis kualitatif dengan menggunakan pendekatan deskriptif. Pengambilan responden/sampel ditentukan secara sengaja (purposive), lokasi penelitian adalah lokasi sentra garam di Indonesia. Hasil penelitian menunjukkan bahwa peningkatan kapasitas kelembagaan garam rakyat yang menopang industri garam di indonesia diklasifikasikan menjadi dua, yaitu terhadap kelembagaan yang ada dan menciptakan kelembagaan yang baru Kedua jenis peningkatan kapasitas kelembagaan garam rakyat tersebut tidak serta merta untuk dijalankan secara bersamaan. Penguatan kelembagaan yang sudah ada merupakan prioritas disertai dengan perbaikan kelemahan-kelemahan yang ada dan penambahan tugas dan tanggungjawab dalam kerangka meningkatkan peran garam rakyat dalam industri pergaraman nasional.
\end{abstract}

Kata Kunci: peningkatan kapasitas; kelembagaan; garam rakyat; industri garam

\begin{abstract}
Ministry of Maritime Affairs and Fisheries (MMAF) has decided that the salt business from upstream to downstream has a strategic business prospects. This policy does not just pay attention to the quantity and quality of salt, but also pay attention to the socio-economic aspects of growers, collectors, processors, traders salt. Moreover, institutional aspects (Cooperative Business Group saltworks and salt) that increased welfare, marketing, selling prices of salt, and the salt imports. The purpose of this study are: (1) Conduct a study on institutional performance and business folk salt; (2) Conducting studies on efforts to establish a buffer salt institution. Methods of data analysis used in this study is a qualitative analysis using descriptive approach. Respondent / sample is determined intentionally (purposive), the study site was the location of the center of the salt in Indonesia. The results showed that the development of institutional capacities of the people who download salt. Both types of salt institutional capacity building of the people are not executed simultaneously. Institutional strengthening of existing ones is a priority along with the improvement of existing weaknesses and additional duties and responsibilities within the framework of enhancing the role of the people in the salt industry nation wide.
\end{abstract}

Keywords: enhancing; capacity; institusional; salt; salt industry 


\section{PENDAHULUAN}

Pada tahun 2012 lalu, produksi garam nasional sudah mencapai swasembada. Produksi tersebut sudah melebihi kapasitas gudang petambak garam, sehingga terjadi penumpukan stok garam rakyat di gudang petambak garam dan belum dapat terjual. Perusahaan tidak dapat menyerap/membeli garam produksi lokal tersebut karena stok garam pada industri pengolahan garam sudah melebihi kebutuhan dengan adanya impor garam yang berlebih pada tahun 2011.

Industri garam tidak bisa menyerap garam rakyat disebabkan oleh beberapa faktor; 1) warna garam rakyat yang terkesan kotor, 2) garam masih basah, dan 3) kadar $\mathrm{NaCl}$ belum sesuai dengan kriteria yang ditetapkan garam industri. Peningkatkan kualitas garam rakyat membutuhkan waktu yang cukup lama, tetapi perbedaan harga garam rakyat tidak signifikan. Kondisi tersebut menyebabkan para petambak garam memilih memproduksi garam dengan kualitas rendah dengan jumlah yang banyak. Produksi garam dengan kadar $\mathrm{NaCl}$ mendekati $100 \%$ hanya dapat dilakukan oleh pabrik garam. Sementara itu, masyarakat hanya dapat memproduksi garam beryodium dengan kadar $\mathrm{NaCl}$ maksimal $90 \%$. Pengelolaan usaha pegaraman masih bersifat tradisional. System usaha pegaraman yang ada seperti cara TUF (Teknik Ulir Filter) maupun Teknologi Tepat Guna dari Kabupaten Indramayu hanya sebatas informasi lokal daerah setempat saja, belum diakui secara nasional (Ismail,2010).

Perbaikan kualitas garam rakyat memerlukan koordinasi diantara stakeholder garam untuk tujuan kesejahteraan rakyat. Tugas pemerintah adalah mengidentifikasi.. permasalahan-permasalahan pergaraman seperti kebutuhan teknologi garam, kelembagaan garam, dan pemasaran. (KKP) Kementerian Kelautan dan Perikanan telah memutuskan bahwa usaha garam dari hulu sampai hilir memiliki prospek usaha yang stategis. Kebijakan ini tidak hanya memperhatikan kuantitas dan kualitas garam, tetapi juga memperhatikan aspek sosial ekonomi para petambak, pengumpul, pengolah dan pedagang garam agar terjadi peningkatan kesejahteraan, pemasaran, harga jual garam, serta impor garam. Peraturan Menteri Perdagangan No. 20 Tahun 2005 tentang Ketentuan Impor Garam mengatur larangan impor garam dalam masa satu bulan sebelum panen raya garam rakyat, selama panen raya garam rakyat dan dua bulan setelah panen raya garam rakyat yang masanya ditentukan oleh KKP.

Kenyataan yang terjadi adalah bahwa impor garam beberapa waktu yang lalu tidak memperhatikan peraturan yang ada. Hal ini terjadi disebabkan adanya kepentingan yang dilakukan oleh segelintir orang atau pihak yang tidak bertanggungjawab. Oleh karena itu, pengawasan di lapangan secara ketat dan punishment dilakukan secara berjenjang bagi pihak-pihak yang melanggar aturan tersebut.

Usaha pegaraman diharapkan dapat dilaksanakan oleh para pelaku utama dengan tujuan yang jelas dan sesuai dengan kapasitasnya masing-masing. Panduan yang terstruktur dapat memberikan langkah-langkah yang tertata dengan baik bagi pelaku usaha pegaraman. Kebijakan perlu didasari prinsipprinsip keterpaduan antara kepentingan pemerintah dan dunia usaha, prinsip demokrasi antara pemerintah pusat, pemerintah daerah dan pelaku utama dan pelaku usaha garam.

Berdasarkan potensi dan permasalahan terkait dengan kelembagaan garam rakyat untuk mendukung industri garam di Indonesia, maka tujuan penelitian ini adalah : (1) Melakukan kajian tentang kinerja kelembagaan dan pelaku usaha garam rakyat; (2) Melakukan kajian tentang upaya pembentukan badan penyangga garam untuk mengawasi produksi dan distribusi garam; (3) Melakukan kajian terkait dengan kinerja POKJA pegaraman pada masing-masing lokasi; dan (4) Melakukan kajian tentang upaya penguatan kelembagaan koperasi sebagai lembaga penyangga garam di lokasi.

\section{METODOLOGI PENELITIAN}

\section{Data, Sumber Data dan Pengumpulan Data}

Penelitian ini mengunakan data primer yang berkaitan dengan kinerja dan performa kelembagaan usaha pegaraman (kelompok usaha garam rakyat/KUGAR dan Koperasi POKJA) masing-masing data primer tersebut diperoleh dari hasil wawancara dengan menggunakan kuesioner terhadap para responden terdiri dari pelaku usaha pegaraman (petambak garam, pedagang pengumpul 
dan pengolah garam konsumsi), Pokja dan koperasi garam yang ditentukan secara sengaja (purposive) dengan pertimbangan bahwa di lokasi penelitian tersebut merupakan lokasi sentra garam di Indonesia. Sedangkan data sekunder dikumpulkan dari laporan tahunan dan statistik Dinas Perikanan Kabupaten dan laporan-laporan hasil penelitian sebelumnya.

\section{Metode Analisis Data}

Metode analisis data yang digunakan dalam kajian ini adalah analisis kualitatif dengan menggunakan pendekatan deskriptif. Pendekatan deskriptif digunakan untuk melihat: (1) kinerja kelembagaan dan pelaku usaha garam rakyat; (2) upaya pembentukan badan penyangga garam untuk mengawasi produksi dan distribusi garam; (3) kinerja POKJA pegaraman pada masing-masing lokasi; (4) upaya penguatan kelembagaan koperasi sebagai lembaga penyangga garam di lokasi.

\section{Waktu dan Penentuan Lokasi Penelitian}

Pelaksanaan kajian ini dilakukan pada tahun 2013 dengan mengambil lokasi penelitian berupa sentra garam di Indonesia (Kabupaten Cirebon, Kabupaten Indramayu, Kabupaten Pati, Kabupaten Rembang, Kabupaten Sampang, Kabupaten Pamekasan, Kabupaten Sumenep), dan lokasi penyangga garam di Indonesia (Kabupaten Jeneponto)

\section{HASIL DAN PEMBAHASAN}

\section{Performa Kelembagaan dan Pelaku Usaha Garam Rakyat}

Pada kegiatan usaha pegaraman, pelaku utama yang terlibat adalah petambak garam, pengumpul, pengolah, pedagang. Berdasarkan status kepemilikan lahan, petambak garam dapat diklasifikasikan menjadi tiga yaitu: 1) Petambak pemilik; 2) Penggarap; dan 3) Sewa. Berdasarkan potensi daya beli, pedagang dapat kategorikan menjadi dua yaitu pedagang kecil dan pedagang besar. Para pelaku tersebut memiliki tugasnya masing-masing yang diharapkan terjadi suatu kemitraan diantara para pelaku tersebut, yaitu saling menghargai, saling menguntungkan, saling memperkuat, dan saling membutuhkan.

Kelembagaan usaha garam yang ada saat ini adalah bentuk Koperasi. Koperasi tersebut sifatnya sebagai penampung dari produk garam anggota, yaitu para petambak. Koperasi juga turut membantu proses produksi, dengan memberikan biaya operasional sesuai dengan kemampuan koperasi tersebut. Permasalahan yeng terjadi adalah koperasi belum dapat menjaga kestabilan harga jual produk yang memberikan keuntungan yang layak.

Pemerintah perlu melakukan intervensi dalam hal kebijakan dalam mendukung kelembagaan garam agar terjalinnya hubungan yang harmonis antar pelaku usaha garam. Kelembagan usaha garam, secara teknis memang perlu dibenahi dalam meningkatkan usaha para anggota guna tercapainya tingkat kesejahteraan yang diinginkan. Beberapa hal yang perlu tersedia di kelembagaan usaha garam adalah:

1. Kelembagaan yang mengawasi tentang teknis pengelolaan tambak untuk menghasilkan garam yang memenuhi aspek kuantitas dan kualitas.

2. Kelembagaan yang mengawasi keputusan pemerintah secara bertanggungjawab, untuk mengawasi terjadinya pelanggaran.

3. Kelembagaan yang memiliki teknologi inovasi sesuai dengan kearifan lokal, sehingga para petambak setempat secara bertanggungjawab mengikuti teknologi yang tersedia baik teknologi pengolahan fisik sampai dengan teknologi pengolahan lanjutan, misal teknologi pengolahan air tua (bittern).

4. Kelembagaan yang secara kekeluargaan menjadi tumpuan para pelaku utama dan pelaku usaha garam dengan pengurus yang memiliki jiwa entreuprener dan cara kerja dengan manajemen yang solid sehingga terkelola secara efisien dan efektif.

\section{Pembentukan Badan Penyangga Garam untuk Mengawasi}

\section{Produksi dan Distribusi Garam}

Pembentukan "Badan Penyangga Garam" (BPG) saat ini sudah sangat diperlukan. Hal ini di latarbelakangi ketersediaan data antara daerah dan nasional belum seragam terkait dengan data produksi, harga garam dan sistem distribusi. Sebagai contoh, perhitungan garam rakyat yang diproduksi berbeda antara KKP 
dengan perhitungan garam secara nasional. Perbedaan perhitungan tersebut dikarenakan perbedaan sumber data, untuk itu diperlukan sistem resi gudang/pencatatan stok garam. Perbedaan sumber data yang cukup besar dapat mengakibatkan pasokan garam impor menjadi berlebih, sehingga akan mengganggu stabilitas harga garam rakyat pada masa panen berikutnya. Saat ini, sudah harus direalisasikan pembentukan lembaga independen yang dapat menghitung dan mengawasi produksi garam dengan tepat. Lembaga tersebut diharapkan dapat memprediksi kuota garam impor yang dibutuhkan sebelum waktu impor, sehingga terdapat kepastian dari segi harga dan kuantitas garam baik bagi petambak garam maupun importir.

Pembentukan Badan Penyangga Garam (BPG) ini bertujuan untuk menstabilkan harga. Apabila harga garam di tingkat petambak garam turun, maka lembaga tersebut membeli garam rakyat sehingga harganya dapat stabil sesuai dengan harga dasar di tingkat petambak garam yang ditentukan oleh Kementrian Perdagangan, Direktorat Perdagangan Luar negeri tentang harga garam. Badan Penyangga Garam dibentuk dan berstatus BUMN yang berskala nasional sehingga dapat mengkoodinir kondisi stok garam antar daerah. Koperasi khusus usaha pegaraman belum ada, dan perannya tidak akan optimal dalam mengkoordinir kondisi stok garam antar daerah. Selama ini, anggota koperasi mempunyai presepsi bahwa koperasi hanya tempat simpan pinjam.

\section{Optimalisasi Kinerja Kelompok Kerja (POKJA) Pegaraman}

Kelompok Kerja (POKJA) adalah
perwakilan dari sekumpulan instansi pemerintahan yang mempunyai tugas dan fungsi yang sama untuk melaksanakan suatu kegiatan bersama dalam mencapai tujuan bersama agar tidak ada tumpang tindih antar kegiatan (Kardono, 2012). Namun demikian, POKJA pusat terdiri dari Kementerian Perekonomian, Kementerian Kelautan dan Perikanan, Kementerian Perindustrian, Kementerian Perdagangan, Kementerian Koperasi kurang begitu terdengar sosialisasinya. POKJA pegaraman sudah ada ditingkat nasional dan daerah. Pokja pegaraman lebih mengarah kepada penanggulangan Gangguan Akibat Kekurangan Yodium (GAKY) sehingga lebih mengarah kepada garam konsumsi saja. Pokja memerlukan suatu aturan dan payung hukum, yang di dukung oleh peraturan menteri, undang-undang dan petunjuk pelaksanaanya yang berisi ikatan dan tugas pokok dan fungsi masing-masing agar dapat melakukan sinergitas antarlembaga.

Desentralisasi menyebabkan terpisahnya penyelenggaraan sistem pemerintahan dari pusat ke daerah sehingga banyak program pusat yang tidak sampai ke daerah (Hoessein, 2002). Permasalahan tersebut menyebabkan kebijakan pemerintahan di daerah dan pusat kurang bersinergi, sehingga banyak program pusat yang tidak sampai ke daerah. Contohnya, pembiayaan daerah yang berasal dari APBD, kebijakan-kebijakan kepala daerah setempat bisa berbeda dengan pemerintah pusat. Hal tersebut menyebabkan keberpihakan kepada kesuksesan program pemerintah daerah.

Masalah desentralisasi dan tujuan antar sektor yang berbeda-beda menyebabkan adanya perbedaan pandangan dan kebijakan masingmasing instansi. Perbedaan ini yang sering kali menyebabkan kurang bisa singkronisasi dan perbedaan data antar instansi (Kurniawan, 2012). Hal tersebut menyebabkan kurang optimalnya kinerja pokja pegaraman baik di tingkat pusat maupun di tingkat daerah.

\section{Penguatan Kelembagaan Koperasi Sebagai Badan Penyangga Garam di lokasi.}

Koperasi pegaraman sudah dibentuk di lokasi sentra produksi garam di Indonesia, baik di Jawa Barat, Jawa Tengah, Jawa Timur, maupun di Sulawesi Selatan. Koperasi yang terbentuk sebagian besar secara khusus menangani tentang garam seperti di Kabupaten Indramayu, Kabupaten Cirebon, Kabupaten Pati, Kabupaten Sumenep dan Kabupaten Jeneponto. Koperasi yang dibentuk merupakan koperasi serba usaha, yaitu koperasi yang tidak hanya mengelola garam tapi juga menangani komoditas lain (komoditas pertanian). Berikut merupakan gambaran koperasi yang sudah terbentuk di lokasi sentra garam di Indonesia (Tabel 1).

Berdasarkan jumlah koperasi (Tabel 1), belum semua koperasi pegaraman tersebut menjalankan perannya sesuai dengan asas, tujuan, prinsip, dan fungsi kelembagaan koperasi di Indonesia. 
Tabel 1. Performa Koperasi Gara di Indonesia.

\begin{tabular}{|c|c|c|c|}
\hline No & Nama Koperasi & Komoditas & Lokasi \\
\hline 1 & Segoro Madu Mina & $\begin{array}{l}\text { Garam krosok dan garam halus } \\
\text { beryodium }\end{array}$ & Kabupaten Indramayu \\
\hline 2 & Garam Sejahtera & Garam Krosok & Kabupaten Indramayu \\
\hline 3 & Mitra Bahari Sejahtera & $\begin{array}{l}\text { Garam krosok dan garam halus dan } \\
\text { briket beryodium, serta komoditas } \\
\text { lainnya (produk pertanian dll) }\end{array}$ & Kabupaten Cirebon \\
\hline 4 & Bumi Nusa & $\begin{array}{l}\text { Garam krosok, garam halus } \\
\text { beryodium }\end{array}$ & Kabupaten Pati \\
\hline 5 & Astagina & Garam krosok & Kabupaten Sumenep \\
\hline 6 & Garam Mekar & $\begin{array}{l}\text { Garam krosok, garam halus } \\
\text { beryodium, garam briket beryodium } \\
\text { dan garam cair/liquid salt }\end{array}$ & Kabupaten Jeneponto \\
\hline
\end{tabular}

Sumber : Data primer diolah 2013

"Tujuan koperasi yang tertuang dalam BAB II Pasal 3 Undang undang RI No. 25 Tahun 1992, yaitu "memajukan kesejahteraan anggota pada khususnya dan masyarakat pada umumnya serta ikut membangun tatanan perekonomian nasional dalam rangka mewujudkan masyarakat yang maju, adil dan makmur berlandaskan Pancasila dan Undang - undang Dasar 1945". Fungsi koperasi tertuang dalam pasal 4 UU No. 25 Tahun 1992 tentang perkoperasian, yaitu: "1) Membangun dan mengembangkan potensi dan kemampuan ekonomi anggota pada khususnya dan masyarakat pada umumnya untuk meningkatkan kesejahteraan ekonomi dan sosialnya. 2) Berperan serta aktif dalam upaya mempertinggi kualitas kehidupan manusia dan masyarakat, 3) Memperkokoh perekonomian rakyat sebagai dasar kekuatan dan ketahanan perekonomian nasional dengan koperasi sebagai gurunya, dan 4) Berusaha untuk mewujudkan dan mengembangkan perekonomian nasional yang merupakan usaha bersama berdasar atas azas kekeluargaan dan demokrasi ekonomi."
Koperasi pegaraman yang ada belum dapat membeli hasil produksi garam rakyat dari anggotanya dan belum bisa menstabilkan harga garam rakyat yang dihasilkan sebagai contoh,

Keberhasilan "Koperasi Garam Mekar" di Desa Boronglangu Kecamatan Arungkeke, Kabupaten Jeneponto, Provinsi Sulawesi Selatan dapat dijadikan contoh dalam menjalankan usaha simpan pinjam, pengolahan garam, dan pemasaran.

Program revitalisasi koperasi terkait erat dengan pembangunan di bidang industri, yang merupakan bagian dari usaha peningkatan kesejahteraan masyarakat mengacu kepada tiga pilar utama yaitu komitmen pemerintah dalam mengembangan usaha skala mikro, dan meningkatkan kualitas kelembagaan koperasi. Koperasi pegaraman diharapkan dapat dijadikan suatu Badan Penyangga Garam (BPG) yang berfungsi untuk menstabilkan harga belum terbentuk, sehingga kestabilan harga dasar di tingkat petambak garam yang ditentukan oleh Kementrian Perdagangan.

Koperasi merupakan institusi atau lembaga atau organisasi yang tumbuh atas dasar solidaritas tradisional dan kerjasama antar individu. Koperasi sangat berperan dalam pembangunan nasional diberbagai bidang, terutama bidang ekonomi dan bidang-bidang lainnya. Peranan koperasi sangat nyata khususnya dalam 
pembangunan nasional dibidang ekonomi karena koperasi banyak berperan dalam hal tersebut (Nurjanah, A. 2012) diantaranya:

- Membantu meningkatkan penghasilan dan kemakmuran khususnya anggota dan masyarakat pada umumnya.

- Membantu meningkatkan kemampuan usaha, baik perorangan maupun masyarakat.

- Membantu pemerintah dalam menyediakan lapangan pekerjaan.

- Membantu usaha meningkatkan taraf hidup masyarakat

- Menyelanggarakan kehidupan ekonomi secara demokratis.

- Membantu pembangunan dan pengembangan potensi ekonomi anggota khususnya dan masyarakat umumnya.

- Memperkokoh perekonomian rakyat sebagai dasar kekuatan dan ketahanan perekonomian nasional.

- Koperasi dapat menjadi pencipta pasar baru dan sumber inovas

- Menjaga neraca pembayaran melalui kegiatan ekspor. Peran koperasi, usaha mikro, kecil dan menengah sangat strategis dalam perekonomian nasional, sehingga perlu menjadi fokus pembangunan ekonomi nasional pada masa mendatang. Koperasi juga berperan dalam pembangunan nasional dibidang sosial karena pada dasarnya koperasi adalah organisasi atau perkumpulan yang bersifat sukarela. Peranan koperasi dibidang ini diantaranya (Nurjanah, A. 2012):

- $\quad$ Menjadi pendorong bagi para anggotanya untuk memiliki semangat kerja sama dalam membangun tatanan sosial masyarakat yang lebih baik.

- Membantu terciptanyanya suatu tatanan sosial yang bersifat demokratis serta melindungi hak dan kewajiban semua orang.

- Membantu terwujudnya suatu kehidupan masyarakat yang tentram dan damai.

Pembangunan koperasi mengalami kemajuan yang cukup mengembirakan jika diukur dengan jumlah koperasi, jumlah anggota, aktiva dan volume usaha. Secara umum, koperasi mengalami perkembangan usaha dan kelembagaan yang mengairahkan. Namun demikian, koperasi masih memiliki berbagai kendala untuk pengembangannya sebagai badan usaha. Hal ini perlu memperoleh perhatian dalam pembangunan usaha koperasi pada masa mendatang. Peran koperasi dalam perekonomian Indonesia paling tidak dapat dilihat dari: (1) Kedudukannya sebagai pemain utama dalam kegiatan ekonomi di berbagai sektor; (2) Penyedia lapangan kerja yang terbesar; (3) Pemain penting dalam pengembangan kegiatan ekonomi lokal dan pemberdayaan masyarakat; (4) Pencipta pasar baru dan sumber inovasi; dan (5) Sumbangannya dalam menjaga neraca pembayaran melalui kegiatan ekspor (Anonim, 2010)

Pemberdayaan koperasi secara terstruktur dan berkelanjutan diharapkan akan mampu menyelaraskan struktur perekonomian nasional, mempercepat pertumbuhan ekonomi nasional, mengurangi tingkat pengangguran terbuka, menurunkan tingkat kemiskinan, menggerakkan sektor riil, dan memperbaiki pemerataan pendapatan masyarakat. Pemberdayaan koperasi juga meningkatkan pencapaian sasaran di bidang pendidikan, kesehatan, dan indikator kesejahteraan masyarakat Indonesia lainnya.

Saat ini, pembangunan koperasi kurang mendapat perhatian karena koperasi kurang memperlihatkan kinerja dan citra yang lebih baik dari masa sebelumnya. Keadaan ini merupakan salah satu bukti bahwa komitmen pemerintah masih kurang dalam pembangunan koperasi. Pembangunan adalah suatu proses yang harus berkelanjutan dan tersistem. Pertanyaan berikutnya bagaimana prospek koperasi pada masa datang. Jawabannya adalah sangat prospektif jika koperasi yang mempunyai jatidiri . Koperasi yang mempraktekkan prinsip-prinsip koperasi dalam organisasi dan usahanya. Koperasi sebagai badan usaha, organisasi dan kegiatan usahanya harus dilakukan berdasarkan prinsip-prinsip koperasi.Karena prinsip koperasi merupakan garis-garis penuntun yang digunakan oleh koperasi untuk melaksanakan nilai-nilai dalam praktek seperti (1) keanggotaan sukarela dan terbuka, (2) pengendalian oleh anggota secara demokratis, (4) partisipasi ekonomi anggota,(5) pendidikan,pelatihan dan informasi, (6) kerjasama diantara koperasi dan (7) kepedulianterhadap komunitas (Anonim, 2010) 
Koperasi yang mampu mengimplementasikan jati dirinya, koperasi tersebut akan mandiri, mampu bersaing dengan kekuatan eonomi lainnya ,mampu memproduksi produk yang sesuai dengan kebutuhan pasar di dalam dan luar negeri. Berdasarkan, aspek hukum dalam Undang-Undang 1945, Koperasi memperoleh hak untuk hidup dan perkembangan di Indonesia. Koperasi yang sudah dibangun selama ini juga jumlahnya sudah cukup besar. Jumlah ini merupakan aset yang harus dipelihara dan diberdayakan agar dapat berkembang membantu pemerintah untuk memerangi kemiskinan dan menyediakan lapangan kerja. Koperasi yang tumbuh saat ini belum mampu mencapai tujuan bersama anggotanya. Anggota harus diberdayakan melalui pendidikan. Pendidikan adalah usaha sadar untuk meningkatkan kemampuan memahami jati diri dan menerapkannya. Disinilah peranan pihak ketiga termasuk pemerintah untuk dapat membangun mereka mencapai tujuannya baik sebagai mediator, fasilitator maupun sebagai kordinator (Anonim, 2010)

Perkembangan koperasi secara nasional di masa datang diperkirakan menunjukkan peningkatan yang signifikan namun masih lemah secara kualitas. Untuk itu, diperlukan komitmen yang kuat untuk membangun koperasi yang mampu menolong dirinya sendiri sesuai dengan jatidiri koperasi. Hanya koperasi yang berkembang melalui praktek melaksanakan nilai koperasi yang akan mampu bertahan dan mampu memberikan manfaat bagi anggotanya.

\section{KESIMPULAN DAN IMPLIKASI KEBIJAKAN}

\section{Kesimpulan}

Peningkatan kapasitas kelembagaan garam rakyat yang menopang industri garam di Indonesia diklasifikasikan menjadi dua. Pertama, yang sifatnya penguatan kelembagaan yang sudah ada (existing institutions), dan Kedua, menciptakan lembaga baru yang merupakan pengembangan dari lembaga yang sudah ada (advantage institutions).

Terkait dengan penguatan kelembagaan yang sudah ada dilaksanakan dengan cara menfungsikan koperasi-koperasi yang sudah ada terutama koperasi garam untuk meningkatkan perannya menjaga kestabilan harga garam rakyat. Mengaktifkan kembali
POKJA garam yang sudah terbentuk, yang merupakan wujud kerjasama secara integral diantara pemangku kepentingan garam tingkat pusat. POKJA ini penting salah satunya untuk menyeragamkan data dan informasi pergaraman nasional; mengawal implementasi kebijakan pemerintah tentang industri garam nasional; dan mensinergikan kebijakan pemerintah pusat dan daerah tentang produksi, stok dan pemasaran.

Dalam rangka pengembangan lembaga yang sudah ada, dilakukan apabila kinerja lembaga yang ada kurang optimal. "Badan Penyangga Garam" merupakan bentuk kelembagaan yang disarankan untuk menata tata niaga garam secara nasional, melindungi petambak garam dan garam rakyat serta, menentukan kuota impor garam.

Kedua jenis peningkatan kapasitas kelembagaan garam rakyat tersebut tidak serta merta untuk dijalankan secara bersamaan. Penguatan kelembagaan yang sudah ada merupakan prioritas disertai dengan perbaikan kelemahan-kelemahan yang ada dan penambahan tugas dan tanggungjawab dalam kerangka meningkatkan peran garam rakyat dalam industri pergaraman nasional.

\section{Implikasi Kebijakan}

Berdasarkan hasil dan pembahasan pada penelitian ini, maka opsi rekomendasi dari kajian ini terdiri dari: (1) Pembentukan badan penyangga garam untuk mengawasi produksi dan distribusi garam, (2) Optimalisasi kinerja POKJA pegaraman pada masing-masing lokasi, (3) Penguatan kelembagaan koperasi sebagai lembaga penyangga garam di lokasi.

\section{DAFTAR PUSTAKA}

Anonim. 2010. Peran Koperasi Dalam Perekonomian Indonesia. (http:// h0404055.wordpress.com/2010/04/02/ peran-koperasi-dalam-perekonomian-indonesia) diunduh tgl 12 Desember 2013

Darmadi. 2013. Penerapan Teknologi Tepat Guna untuk Mengoptimalkan Produksi Garam Rakyat di Desa Tanjakan, Kecamatan Krangkeng, Kabupaten Indramayu. Darmadi's Blog Berbagi Informasi Dalam Inovasi, 30 
Januari 2013. (Http://dhamadharma. wordpress.com/2013/01/30/penerapan-teknologi-tepat-guna-untuk-mengoptimalkan-produksi-garam-rakyat-di-desa-tanjakan-kecamatan-kerangkeng-kabupaten-indramayu, diunduh tanggal 13-12-2013).

Hoessein, B. 2002. Kebijakan Desentralisasi. Jurnal Administrasi Negara Vol. I, No. 2 Maret 2002. (http://ejournal.narotama. ac.id/files/kebijakan\%20desentralisasi .pdf, diunduh tanggal 12-12.2013).

Indonesia. 2004. Penunjukan Surveyor Sebagai Pelaksana Verifikasi Atau Penelusuran Teknis Impor Garam. Keputusan Menteri Perindustrian dan Perdagangan Republik Indonesia No. 456/Mpp/Kep/7/2004.

2004. Perubahan Atas Peraturan Menteri Perdagangan RI No.20/M-DAG/ PER/9/2005 tentang Ketentuan Impor Garam. Menteri Perdagangan RI. Peraturan Menteri Perdagangan RI No.44/M-DAG/PER/10/2007.

2004. Perubahan Keputusan Menteri Perindustrian dan Perdagangan No.360/ MPP/Kep/5/2004 tentang Ketentuan Impor Garam. Menteri Perindustrian dan Perdagangan RI. Keputusan Menteri Perindustrian dan Perdagangan RI No.376/MPP/Kep/6/2004

2005. Larangan Impor Garam pada tahun 2005. Surat Menteri Perdagangan RI No.425/M-DAG/6/2005 tanggal 15 Juni 2005.

Ismail. 2010. PenerapanTeknologi Tepat Guna Untuk Mengoptimalkan Produksi Garam Rakyat di Desa Tanjakan Kecamatan Kerangkeng Kabupaten Indramayu (http://dhamadharma. Wordpress. com/2013/01/30/penerapan-teknologi-tepat-guna-untuk-mengoptimalkan-produksi-garam-rakyat-di-desa-tanjakan-kecamatan-kerangkeng-kabupaten-indramayu).diunduh tanggal 21 Desember 2013.

Kardono, P. 2012. Lampiran 15 Keputusan Deputi Bidang Informasi Geospasial Tematik Badan Infomrasi Geospasial, Standard Operating Procedures Koordinasi
Sektoral DinamikaSumberdaya.(http:// jdih.big.go.id/resources/files/law/ LAM_15_SK_NO._17_2012_09.08.2012. pdf, diunduh pada tanggal 13-12-2013).

Kementerian Perdagangan. 2005. Peraturan Menteri Perdagangan No. 20 Tahun 2005 tentang Ketentuan Impor Garam.

Kementrian Kelautan dan Perikanan. 2010. Program Swasembada Garam Nasional. Direktorat Jenderal Kelautan, Pesisir dan Pulau-Pulau Kecil.

Kementrian Perdagangan. 2011. Surat Keputusan tentang Penetapan Harga Penjualan Garam di Tingkat Petani Garam. Dirjen. S K Dirjen Perdagangan Luar Negeri, Kementerian Perdagangan No. 02/DAGLU/PER/5/2011.

Kementrian Perindustrian. 2004. Pengecualian Atas Ketentuan Impor Garam Untuk Industri dan Pemberian Kuasa Penerbitan Persetujuan Impor. Keputusan Menteri Perindustrian dan Perdagangan Republik Indonesia No. 455/Mpp/Kep/7/2004.

Kurniawan, T. dan Azizi, A. (2012). Dampak Kebijakan Impor Dan Kelembagaan Terhadap Kinerja Industri Garam Nasional. Seminar Dalam Rangka Diklat Pelatihan Peneliti Tingkat Pertama Golongan VIII di Cibinong Tanggal 11 Juni 2012.

Nurjanah, A. 2012. Peranan Koperasi Dalam Pembangunan Sosial Dan Ekonomi Indonesia. (http://ameawatie.blogspot. com/2012/11/peranan-koperasi-dalam pembangunan.html) diunduh tanggal 12 Desember 2013. 